\title{
Using of date palm fiber mixed with other lignocelluloses toward Pleurotus ostreatus (Higher Basidiomycetes) cultivation
}

\author{
Mustafa Nadhim Owaid ${ }^{1,2 *}$, Idham Ali Abed ${ }^{3}$, Sajid Salahuddin Saleem Al-Saeedi ${ }^{2}$ \\ ${ }^{1}$ Al-Athar School, Heet Education, General Directorate for Education of Anbar, Ministry of Education, Hit, Anbar 31007, Iraq; ${ }^{2}$ Department of \\ Biology, College of Science, University of Anbar, Ramadi, Anbar 31001, Iraq; ${ }^{3}$ Department of Soil Science and Water Resources, College of \\ Agriculture, University of Anbar, Ramadi, Anbar 31001, Iraq
}

\section{A B S T R A C T}

\begin{abstract}
Based on the availability of agro-wastes materials like wheat straw (S1), white sawdust (S4), date palm fiber (S5) and their combinations S2 (70\% wheat straw, 20\% white sawdust and 10\% date palm fiber) and S3 (50\% wheat straw, 30\% white sawdust and $20 \%$ date palm fiber); cultivation of oyster mushroom Pleurotus ostreatus was successful thereof. The longer mycelium complete time within bags was 17 days on sawdust (S4), in contrast, the short time for mycelium overgrew was completed after $13 \mathrm{~d}$ on S3. In significant (P <0.05), S2 was given the higher growth intensity level than other substrates at $3^{\text {rd }}$ level (vigorous mycelial growth), while the S3 showed $2^{\text {nd }}$ level (moderate) as a less growth intensity level. Conversely, lesser time for primordial formation of $P$. ostreatus was outreach one week on S3 which given best flushes number (four) compared as other substrates (1-3 flushes). Also, the best total yield was harvested 204.28 $\mathrm{g} \mathrm{bag}^{-1}$ with biological efficiency $51.78 \%$ from S3, whereas S4 showed the poorer yield only $12.5 \mathrm{~g} \mathrm{bag}^{-1}$.
\end{abstract}

Keywords: Bio-recycling; Cellulosic residues; Cultivation; Date palm wastes; Oyster mushroom

\section{INTRODUCTION}

Pleurotus spp. is one of 24 edible mushrooms cultivated commercially in special cultivation rooms/farms (Thomas and Schumann, 1993). After white button mushroom; the oyster mushroom is the second most important mushrooms in production in worldwide, Pleurotus species are excellently edible and nutritious, rank among one of the most widely cultivated mushrooms in the world, accounting for $25 \%$ of total world production of cultivated mushrooms. Seventy species approximately of Pleurotus were recorded and new species are discovered (Chang and Miles, 2004). Cultivation of oyster mushroom is a biotechnological process for lingo cellulosic wastes recycling. It might be the only current process that combines the production of fresh food with the reduction of the environmental pollutants (Sanchez, 2010). Thus, this fungus is important to bio-convert/bio-recycle cellulosic matters to a rich protein food (Gupta et al., 2013).
Pleurotus ostreatus is source for essential amino acids, mineral and vitamins (Santos-Neves et al., 2008). It is important source for trace elements and its nutritional source low caloric value (Badu et al., 2011). Pleurotus species have a high medicinal value due to possess significant anti-inflammatory, antiviruses (Carvalho et al., 2007), antioxidant, anticancer (Kim et al., 2009), antimicrobial (Akyuz et al., 2010; Alheeti et al., 2013), anti-parasitic (David et al., 2012) and antifungal activities (Owaid et al., 2015a).

Pleurotus spp. can be cultivated on a wide variety of substrates containing lignin, cellulose and hemicellulose (Gregori et al., 2007) such soybean straw, paddy straw, coffee pulp, cotton wastes, corn cobs wastes (Poppe, 2004), bean straw, crushed bagasse, molasses wastes (Ahmed et al., 2009), cardboard and paper wastes (Al-Issawy, 2011, Kulshreshtha et al., 2013) and trees sawdust with rice bran (Owaid et al., 2015b). Recently, Pleurotus ostreatus was produced on some date palm wastes such empty palm fruit

\footnotetext{
*Corresponding author:

Mustafa Nadhim Owaid, Al-Athar School, Heet Education, General Directorate for Education of Anbar, Ministry of Education, Hit, Anbar 31007, Iraq. Emails: mustafa@alheeti.com, mustafanowaid@gmail.com
} 
bunch (Tabi, 2008), date palm leaves and alfalfa (Daneshvar and Heidari, 2008), date palm wastes such fibers, stalk and base stalk (Hassan, 2011), date palm leaves (Kabirifard et al., 2012; Alananbeh et al., 2014) and date palm fibers (Alheeti, 2013; Owaid et al., 2014) mixed with other cellulosic wastes. Also, Mohamad et al. (2008) used empty palm fruit bunch for growth of Pleurotus sajor-caju.

Date palm residues represent a major quantity of biomass as lignocellulose materials. These biomasses are mostly made up of carbohydrates including cellulose and hemicelluloses, bonded with lignin (Al-Jabray et al., 2005). In Iraq, the number of date palm trees declined to 8 million approximately according to Iraqi Central Organization for Statistics because of carelessness (Ismail et al., 2010), therefore; more quantities of residues come out within environment from the carelessness or management of date palm trees, which use as energy by burn some its parts that lead more of air pollutants. The aim of this study to prepare low cost substrates from date palm fibers mixed with wheat straw and white sawdust then amended with some nutrients 5 percent powder of local rock phosphate to improve their nutritional value in Pleurotus ostreatus (blue variety) production.

\section{MATERIALS AND METHODS}

\section{Strains}

Blue oyster mushroom species Pleurotus ostreatus is obtained from Mushroom Box Company, Monmouth, UK, in form spawn and sub cultured it on Potato Dextrose Agar medium at $25 \mathrm{C}^{\circ}$ for this experiment. Spawn was achieved on millet Pennisetum americanum seeds as mentioned by Stamets and Chilton (1983).

\section{Substrates}

In this experiment, using locally agro-residual wastes, available in Hit city, Anbar Province, Iraq, were wheat straw (1-5) cm, white sawdust from factories of wood and fibers of Iraqi date palm Phoenix dactylifera L., called (Fibrillum), which first chopped into small pieces $(5 * 5)$ $\mathrm{cm}$ and mixed. Five combinations were used in this experiment; S1 (wheat straw), as a control, S2 (70\% wheat straw, 20\% white sawdust and 10\% date palm fiber), S3 (50\% wheat straw, $30 \%$ white sawdust and $20 \%$ date palm fiber), S4 (only white sawdust) and S5 (only date palm fibers). All mixtures were supplemented with $5 \%$ rock phosphate based on dry matter is brought from desert western Anbar.

\section{Substrates preparation and mushroom cultivation}

After soaking of substrates, all mixtures were pasteurized using boiling in water for $2 \mathrm{~h}$, cooled, put on clean place to drain out excess water and mixed with five percent rock phosphate powder. Inoculation $4 \%$ mushroom spawn (based on wet matter) with $1.5 \mathrm{~kg}$ substrate was achieved in layers method that packed in polyethylene bags which capacity $30 * 50 \mathrm{~cm}$ then closed. The inoculated bags were transferred into incubation room, darkly incubated at $25^{\circ} \mathrm{C}$ and $90 \%$ relative humidity for spawn running. during the fruiting stage, the bags were opened when the mycelia had covered all the substrate after 3-4 days, shocked using $11-20^{\circ} \mathrm{C}$ for 2 days, lighted $12 \mathrm{~h} / \mathrm{d}$ using fluorescent light and fresh aeration twice a day using method of Alheeti (2013) with some modifications. Spray watering was also given twice a day with $90 \%$ humidity.

Determinations are included time of mycelial growth, mushrooms' mycelia intensity, pin-heads (primordia) appearance, flushes numbers, total yield, biological efficiency, fruit bodies' number and their sizes. Biological efficiency was calculated according to equation (weight of wet mushrooms harvested/weight of dry substrate taken) $\times 100$ (Bisaria et al., 1987).

\section{Statistical analysis}

The data, collected in triplicates, has been expressed by its mean value and standard deviation (SD). The results were subjected to one way analysis of variance (ANOVA) using SAS statistical program for windows (version 9.0, SAS Institute Inc., Cary, NC, USA). The significance of difference was determined according to Duncan's Multiple Range Test (DMRT). P values $<0.05$ were considered to be statistically significant.

\section{RESULTS AND DISCUSSION}

The results of state of fungus Pleurotus ostreatus (grey) before fruiting bodies emergence were appeared in Table 1 and Fig. 1. Type of agro-substrate significantly $(\mathrm{P}<0.05)$ effected on mycelium completion time (MCT). The longer MCT within bags was 17 days on white sawdust substrate (S4), as a least period for mycelium growth completion. While the completion was achieved after $15 \mathrm{~d}$ and $14 \mathrm{~d}$ on S2 (70\% wheat straw, 20\% white sawdust and 10\% date palm fiber) and S5 (date palm fiber), respectively; compared with the control (wheat straw alone, S1) at average $16 \mathrm{~d}$. In contrast, the short time for mycelium overgrew completed after $13 \mathrm{~d}$ on S3 substrate ( $50 \%$ wheat straw, 30\% white sawdust and $20 \%$ date palm fiber) as a best result, significantly $(\mathrm{P}<0.05)$.

These results are in line with the finding of Kabirifard et al. (2012) they reported, this fungus grew on date palm leaves faster than wheat stubble. The lower time to overgrow mycelia of P. ostreatus on substrate may be return 

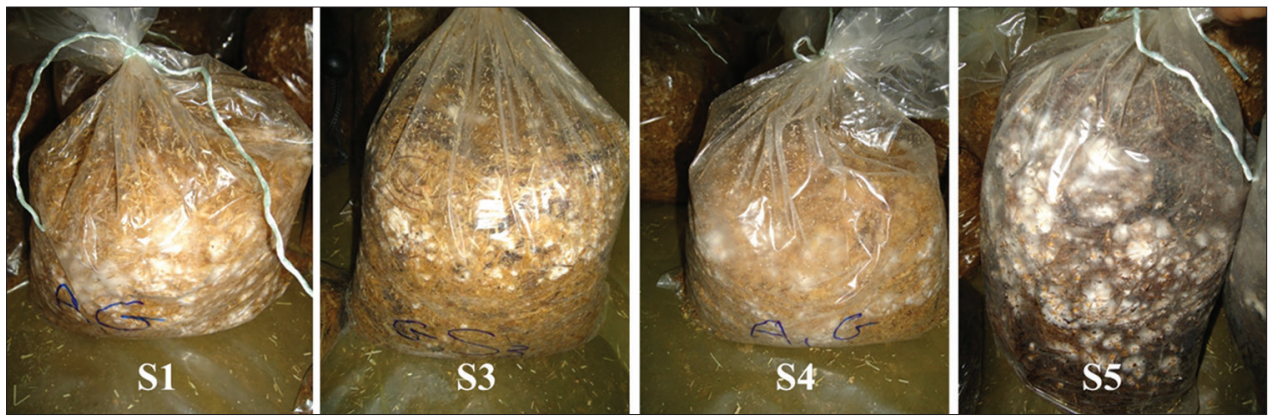

Fig 1. Appearance of mushroom mycelial growth within cultivation bags after 10 days.

Table 1: Status of oyster mushroom's mycelium before fruits formation in substrates

\begin{tabular}{lccc}
$\begin{array}{l}\text { The used } \\
\text { agro-wastes }\end{array}$ & $\begin{array}{c}\text { Mycelium } \\
\text { Completion Time } \\
\text { (MCT) (days) }\end{array}$ & $\begin{array}{c}\text { Growth } \\
\text { Intensity } \\
\text { Level (GIL) }\end{array}$ & $\begin{array}{c}\text { Primordial } \\
\text { Formation Time } \\
\text { (PFT) (days) }\end{array}$ \\
\hline S1 & $16^{\mathrm{b}}$ & $2.6^{\mathrm{ab}}$ & $11.0^{\mathrm{c}}$ \\
S2 & $15^{\mathrm{c}}$ & $3.0^{\mathrm{a}}$ & $10.0^{\mathrm{c}}$ \\
S3 & $13^{\mathrm{e}}$ & $2.0^{\mathrm{b}}$ & $7.3^{\mathrm{d}}$ \\
S4 & $17^{\mathrm{a}}$ & $2.3^{\mathrm{ab}}$ & $29.0^{\mathrm{b}}$ \\
S5 & $14^{\mathrm{d}}$ & $2.6^{\mathrm{ab}}$ & $34.0^{\mathrm{a}}$ \\
Mean \pm MSD & $15 \pm 0.00$ & $2.5 \pm 0.44$ & $18.2 \pm 1.03$ \\
\hline
\end{tabular}

Legend: Growth Intensity Level (GIL): 1: Light, 2: Moderate, 3: Vigorous. S1: wheat straw substrate, S2; $(70 \%$ wheat straw, $20 \%$ white sawdust and $10 \%$ date palm fiber), S3: (50\% wheat straw, $30 \%$ white sawdust and $20 \%$ date palm fiber), S4: White sawdust, S5: Date palm fiber. Values followed by the same superscript letter (s) along each column are not significantly different by Duncan's multiple range test (DMRT) $(P<0.05)$. Values in the same column followed by a common superscript letter do not differ significantly $(P>0.05)$. MSD: Mean of standard deviation

to capability of this fungus for enzymes producing to decompose various aromatic compounds (Hassan, 2011). Also, Hassan et al. (2008) induced for using P. ostreatus as microbial method for decomposing mixture of date palm leaves with wheat straw, which lead to decrease lignin and phenolic content and increase digestion of dry matter compared with the digestion by chemical method due to produce many enzymes. From other side, kind of substrate affected on speed of mycelial growth and time covered of the whole plate by mycelia (Kashangura, 2008).

From other side, growth intensity level (GIL) was assessed according to three levels (1: Light, 2: Moderate, 3: Vigorous) which estimated to $3^{\text {rd }}$ level approx. as a mean. In significant $(\mathrm{P}<0.05), \mathrm{S} 2$ was given the higher GIL than other substrates at $3^{\text {rd }}$ level (vigorous mycelial growth). S1, S4 and S5 were given average 2.5 while the S3 showed $2^{\text {nd }}$ level (moderate) as a less GIL, Table 1. These results, above, reflect on primordial formation time (PFT). Conversely, lesser time for primordial formation of $P$. ostreatus was outreach 7 days on $\mathrm{S} 3$, significantly $(\mathrm{P}<0.05)$; comparison with $11 \mathrm{~d} \& 10 \mathrm{~d}$ on S2 and S1 (control), respectively. Whereas the more time for this test was achieved on S4 \& S5 at average 29 d \& 34 d, respectively.
S3 had lower values in MCT, GIL and PFT which were $13 \mathrm{~d}, 2^{\text {nd }}$ level (moderate) and $7.3 \mathrm{~d}$, respectively. However, the higher values was showed for same tests on S4 $(\mathrm{MCT}=17 \mathrm{~d}), \mathrm{S} 2(\mathrm{GIL}=$ third level) and S5 $(\mathrm{PFT}=34 \mathrm{~d})$. And according to Table 4, have no correlation between GIL and PFT. Consequently, MCT has a negative correlation $(r=-0.61)$ with PFT and $(r=-0.56)$ with GIL at probability level $<0.01$ and $<0.05$, respectively. Generally, that was reflects on $\mathrm{S} 3$ substrate which completed mycelium growth al lesser time (13 d), that led to decline the time with PFT and became economic to food production. Dependence of this time was important for reducing production period/ cycle of mushroom economically, therefore; the substrate 3 was best formula in this side.

Intensity of mycelia may be good to raise the productivity and number of fruits as showed in Tables $2 \& 3$. These results are in agreement with the finding of Alheeti (2013) who concluded that the similar to S3 is good source for some Pleurotus species growing and production. The extended time of MCT of S4 attributed to the substrate which composed from sawdust alone that unsuitable for oyster mushroom cultivation thereby it must be mixed with other agro-residues. These results are in agreement with the finding of Owaid et al. (2014), they reported that the sawdust extract exhibit poor mycelial growth of oyster mushroom $P$. ostreatus for white and grey strains in vitro. Davis and Aegerter (2000), emphasized that sawdust must be not used alone but in mixtures with various agro-residues. Also, Onuoha (2007) mentioned that the sawdust may be reduced oyster mushroom production relatively. The reason may be that sawdust which produced in wood factories was pretreated with fungicides (Kalpana et al., 2011). In contrast, the trees sawdust alone supplemented with rice bran succeeded in oyster mushroom cultivation (Owaid et al., 2015b), while in this study, the sawdust of wood factories supplemented with rock phosphate as a source of $\mathrm{CaCO}_{3}$ and phosphorus.

Number of flushes which achieved in this work reached almost to mean 3 flushes. S3 was given best number of 
Table 2: Quantity characteristics of produced oyster mushroom on various agro-substrates

\begin{tabular}{lccccc}
\hline Agro-wastes & Flushes number & Flushes weight $\mathbf{( g )}$ & BE $(\%)$ & Fruits number & Fruit weight (g) \\
\hline S1 & $3.00^{\mathrm{b}}$ & $144.30^{\mathrm{b}}$ & $41.90^{\mathrm{b}}$ & $23.0^{\mathrm{a}}$ & $6.30^{\mathrm{c}}$ \\
S2 & $3.00^{\mathrm{b}}$ & $109.41^{\mathrm{c}}$ & $30.50^{\mathrm{c}}$ & $11.3^{\mathrm{b}}$ & $9.70^{\mathrm{b}}$ \\
S3 & $3.66^{\mathrm{a}}$ & $204.28^{\mathrm{a}}$ & $51.78^{\mathrm{a}}$ & $22.5^{\mathrm{a}}$ & $9.35^{\mathrm{b}}$ \\
S4 & $1.00^{\mathrm{d}}$ & $12.50^{\mathrm{e}}$ & $2.90^{\mathrm{e}}$ & $1.0^{\mathrm{c}}$ & $12.50^{\mathrm{a}}$ \\
S5 & $2.00^{\mathrm{c}}$ & $76.53^{\mathrm{d}}$ & $15.48^{\mathrm{d}}$ & $11.0^{\mathrm{b}}$ & $6.96^{\mathrm{c}}$ \\
Mean \pm MSD & $2.53 \pm 0.25$ & $109.40 \pm 10.05$ & $28.51 \pm 2.54$ & $13.1 \pm 1.20$ & $8.93 \pm 0.59$ \\
\hline
\end{tabular}

S1: Wheat straw substrate, S2; (70\% wheat straw, $20 \%$ white sawdust and $10 \%$ date palm fiber), S3: (50\% wheat straw, $30 \%$ white sawdust and $20 \%$ date palm fiber), S4: White sawdust, S5: Date palm fiber. BE: Biological efficiency. Values followed by the same superscript letter (s) along each column are not significantly different by Duncan's multiple range test (DMRT) $(\mathrm{P}<0.05)$. Values in the same column followed by a common superscript letter do not differ significantly $(P>0.05)$. MSD: Mean of standard deviation

Table 3: Quality characteristics of produced oyster mushroom fruits on various agro-substrates

\begin{tabular}{|c|c|c|c|c|c|}
\hline The used agro-wastes & Diameter of cap mm & Thickness of cap mm & Length of stem mm & Diameter of stem mm & D/L ratio \\
\hline$\overline{\mathrm{S} 1}$ & $70.0^{b}$ & $3.2^{b}$ & $49.0^{b}$ & $8.9^{b}$ & $1.4^{c}$ \\
\hline S2 & $70.3^{b}$ & $3.7^{\mathrm{ab}}$ & $44.3^{c}$ & $11.6^{\mathrm{a}}$ & $1.5^{\mathrm{bc}}$ \\
\hline S3 & $88.6^{a}$ & $3.7^{\mathrm{ab}}$ & $36.6^{d}$ & $11.0^{\mathrm{ab}}$ & $2.4^{\mathrm{a}}$ \\
\hline S4 & $66.0^{b}$ & $2.1^{\mathrm{c}}$ & $61.0^{a}$ & $11.6^{a}$ & $1.1^{\mathrm{d}}$ \\
\hline S5 & $59.3^{c}$ & $4.0^{\mathrm{a}}$ & $35.0^{d}$ & $10.3^{a b}$ & $1.7^{\mathrm{b}}$ \\
\hline Mean \pm MSD & $70.8 \pm 2.36$ & $3.38 \pm 0.26$ & $45.2 \pm 1.98$ & $10.7 \pm 1.11$ & $1.6 \pm 0.08$ \\
\hline
\end{tabular}

Legend: S1: Wheat straw substrate, S2; (70\% wheat straw, $20 \%$ white sawdust and 10\% date palm fiber), S3: (50\% wheat straw, 30\% white sawdust and $20 \%$ date palm fiber), S4: White sawdust, S5: Date palm fiber. D/L ratio: Diameter of cap/length of stem ratio. Values followed by the same superscript letter (s) along each column are not significantly different by Duncan's multiple range test (DMRT) $(P<0.05)$. Values in the same column followed by a common superscript letter do not differ significantly $(P>0.05)$. MSD: Mean of standard deviation

Table 4: Correlation among measurements of this experiment

\begin{tabular}{|c|c|c|c|c|c|c|c|c|c|c|c|c|c|}
\hline Features & $\begin{array}{l}\text { Flushes } \\
\text { number }\end{array}$ & $\begin{array}{c}\text { Flushes } \\
\text { weight }\end{array}$ & $\begin{array}{c}\begin{array}{c}\text { Fruits } \\
\text { number }\end{array} \\
\end{array}$ & $\begin{array}{c}\text { Fruit } \\
\text { weight }\end{array}$ & $\begin{array}{c}\text { Diameter } \\
\text { stem }\end{array}$ & $\begin{array}{c}\text { Length } \\
\text { stem }\end{array}$ & $\begin{array}{c}\text { Diameto' } \\
\text { cap }\end{array}$ & $\begin{array}{c}\text { Thicknes } \\
\text { s cap }\end{array}$ & $\begin{array}{l}\mathrm{D} / \mathrm{L} \\
\text { ratio }\end{array}$ & BE & MCT & $\begin{array}{l}\text { Primordi } \\
\text { al form }\end{array}$ & $\begin{array}{c}\text { Growth } \\
\text { intensity }\end{array}$ \\
\hline Flush number & 1.000 & & & & & & & & & & & & \\
\hline Flushes weight & 0.000 & 1.000 & & & & & & & & & & & \\
\hline Fruits number & $-0.591^{\star}$ & -0.085 & 1.000 & & & & & & & & & & \\
\hline Fruit weight & $-0.506^{\star}$ & 0.012 & $0.909^{\star *}$ & 1.000 & & & & & & & & & \\
\hline Diameter stem & $-0.611^{*}$ & 0.063 & $0.847^{\star *}$ & $0.925^{\star \star}$ & 1.000 & & & & & & & & \\
\hline Length stem & 0.259 & 0.017 & $-0.530^{*}$ & -0.495 & $-0.725^{\star *}$ & 1.000 & & & & & & & \\
\hline Diameter cap & 0.291 & -0.240 & -0.146 & -0.278 & -0.485 & $0.639^{\star \star}$ & 1.000 & & & & & & \\
\hline Thickness cap & -0.168 & -0.008 & $-0.588^{*}$ & $-0.604^{* *}$ & -0.484 & $0.589^{*}$ & 0.160 & 1.000 & & & & & \\
\hline $\mathrm{D} / \mathrm{L}$ ratio & -0.365 & -0.073 & $0.708^{* *}$ & $0.775^{\star \star}$ & $0.538^{*}$ & 0.142 & 0.124 & -0.251 & 1.000 & & & & \\
\hline$B E$ & -0.033 & -0.034 & $0.651^{* *}$ & $0.560^{*}$ & 0.504 & $-0.693^{\star *}$ & -0.199 & $-0.882^{\star \star}$ & 0.131 & 1.000 & & & \\
\hline MCT & $-0.641^{\text {** }}$ & 0.013 & $0.917^{* *}$ & $0.986^{\star *}$ & $0.935^{\star *}$ & -0.481 & -0.306 & $-0.497^{\star}$ & $0.763^{\star \star}$ & 0.493 & 1.000 & & \\
\hline Primordial form & $0.973^{\star \star}$ & 0.000 & $-0.573^{*}$ & -0.485 & -0.503 & 0.058 & 0.140 & -0.238 & -0.471 & 0.0488 & $-0.618^{\star \star}$ & 1.000 & \\
\hline Growth intensity & -0.200 & 0.000 & $-0.640^{* *}$ & $-0.688^{\star *}$ & -0.476 & 0.401 & -0.013 & $0.929^{\star *}$ & -0.493 & $-0.792^{\star *}$ & $-0.568^{*}$ & -0.206 & 1.000 \\
\hline
\end{tabular}

BE: Biological efficiency, MCT: Mycelium completion time, D/L: Diameter of cap/length of stem ratio, ${ }^{*} \mathrm{P}<0.05$, ${ }^{* *} \mathrm{P}<0.01$

flushes around 4 flushes significantly $(\mathrm{P}<0.05)$ compared as other substrates; three flushes on S1 \& S2 then declined to two flushes on S5 and one with S4 substrate. S3 was given best flushes number, which exhibited preferable results before fruits harvesting (Table 1). That agreement with the mentioned results by Alheeti et al. (2013) who used same formula which prepared it by pasteurization but in this study used the boiling method to prepare these mixtures. These results were attributed to use mixture from more than one substrate instead of which composed from one (Hamad, 2005; Hassan, 2011; Owaid et al., 2014).

According to flushes number, productivity increased significantly $(\mathrm{P}<0.05)$. The best total yield was harvested
$204.28 \mathrm{~g} \mathrm{bag}^{-1}$ from the formula S3 (Table 2) compared with yield of control media (S1) $144.30 \mathrm{~g} \mathrm{bag}^{-1}$. Whereas, S4 (white sawdust) showed the poorer yield only $12.5 \mathrm{~g} \mathrm{bag}^{-1}$ from one flush only that given one fruit body and lead to $3 \%$ biological efficiency (BE) too, that due to either phenol content of wood of a factories (Ranjini and Padmavathi, 2012) or this wood pretreated by fungicides in wood processing to protect wood from decomposed that lead to decrease mycelial growth (Kalpana et al., 2011). This agrees with Davis and Aegerter (2000) and Owaid et al. (2014) who mentioned to use sawdust of factories in mixture but not alone. The best significant $(\mathrm{P}<0.05)$ biological efficiency (approx. 52\%) was seen on S3 substrate compared with the control (S1) almost $42 \%$. That is agreement with 
observation of Alheeti (2013). Generally, the fruits number reached to a mean 13 fruiting bodies at a rate of weight $8.93 \pm 0.59 \mathrm{~g}$ a fruit body (Table 2). The reason of high $\mathrm{BE}$ in S2 and S3 return to these combinations which have been formed from more one substrate or to use date palm wastes in these mixtures that seen and agreed with results of Hassan (2011) and Alheeti (2013).

About quality characteristics which related with fruit body size; cap diameter of $P$. ostreatus which grew on S3 was bester $(88.6 \mathrm{~mm})$ comparison as caps of fruits which harvested from S1 (control) $70 \mathrm{~mm}$, whilst the least diameter of cap $59.3 \mathrm{~mm}$ for fruits on S5 (date palm fibers) that given thickness of cap reached to $4 \mathrm{~mm}$ as a best thickness, followed by S2 \& S3 at a value $3.7 \mathrm{~mm}$. The lowest thickness was seen in fruits which formed on sawdust (S4). The higher length of fruit's stem reached to $61 \mathrm{~mm}$ on S4, while the mixtures S2 \& S5 had declined the stem length to 36.6 and $35 \mathrm{~mm}$ respectively, compared with $49 \mathrm{~mm}$ for fruits of control. Diameter of stem increased with all agro-mixtures compared with $8.9 \mathrm{~mm}$ for control (wheat straw). Favorability, D/L ratio reached to 2.4 with fruit bodies of the substrate $\mathrm{S} 3$, whereas it declined to 1.1 with sawdust's fruits.

Some results linked together in positive or negative correlations that is explain the reasons of increasing or decreasing some properties (Table 4). Diameter of stem linked in positive correlation $(r=0.92 \& r=0.93)$ with weight of fruits and MCT respectively, on one side, and negative correlation $(r=-0.72)$ with its length on another side, significantly $(\mathrm{P}<0.01)$. Also, the last had negative correlation $(r=-0.69)$ with BE, that explicated the declining in total yield with fruits that have length stem in same probability. BE linked with fruits number and fruits weight in positive correlation $(\mathrm{r}=0.65$ and $\mathrm{r}=0.56)$ significantly at level $\mathrm{P}<0.01 \& \mathrm{P}<0.05$, respectively, this is explain increasing $\mathrm{BE}$ in some mixtures.

\section{CONCLUSION}

Four agro-mixtures, wheat straw (S1), S2 (70\% wheat straw, $20 \%$ white sawdust and 10\% date palm fiber), S3 (50\% wheat straw, $30 \%$ white sawdust and $20 \%$ date palm fiber), white sawdust (S4) and date palm fibers (S5), were used to cultivate oyster mushroom Pleurotus ostreatus successfully. In conclusion, significantly $(\mathrm{P}<0.05) \mathrm{S} 3$ had the short time for mycelium overgrew after 13 days and showed moderate growth intensity level, that led to lesser time for primordial formation of P. ostreatus was outreach 7 days. Also, S3 was given best results toward flushes number (four flushes) compared with other mixtures (1-3), total yield $204.28 \mathrm{~g}$ bag $^{-1}$ and biological efficiency $51.78 \%$.

\section{Author contributions}

M. N. O. made a major contribution to achieve this test and write this paper. I. A. A. and S. S. S. A. were involved in overall planning, supervision and review.

\section{REFERENCES}

Ahmed, S. A., J. A. Kadam, V. P. Mane, S. S. Patil and M. M. V. Baig. 2009. Biological efficiency and nutritional contents of Pleurotus florida (Mont.) Singer cultivated on different agro-wastes. Nat. Sci. 7: 44-48.

Akyuz, M., A. N. Onganer, P. Erecevit and S. Kirbag. 2010. Antimicrobial activity of some edible mushrooms in the Eastern and Southeast Anatolia Region of Turkey. Gazi Univ. J. Sci. 23: 125-130.

Alananbeh, K. M., Bouqellah, N. A. and Al Kaff, N. S. 2014. Cultivation of oyster mushroom Pleurotus ostreatus on date-palm leaves mixed with other agro-wastes in Saudi Arabia. Saudi J. Biol. Sci. 21: 616-625.

Alheeti, M. N. O. 2013. Testing efficiency of different agriculture media in growth and production of four species of oyster mushroom Pleurotus and evaluation the bioactivity of tested species. Ph.D. dissertation, Dep. Biology, College of Science, University of Anbar, Iraq.

Alheeti, M. N. O., S. S. S. Al-Saeedi, I. A. Al-Assaffii and V. Sabaratnam. 2013. Antifungal activities of mycelia and culture filtrate of four oyster mushroom species (Pleurotus spp.) against pathogenic fungi. The $7^{\text {th }}$ International Medicinal Mushroom Conference, Beijing, China.

Al-Issawy, K. J. F. 2011. Improve the local components of the substrate to increase the production oyster mushroom Pleurotus ostreatus. M.Sc. Thesis, College of Agriculture, University of Anbar, Iraq.

Al-Jabray, K. M. A., M. A. Namma and A. S. Mahdi. 2005. Lignin and cellulose content in some parts of date palm Phoenix dactlifera L. cultivars Hillawi and Barhi. Basrah Date Palm Res. J. 4: 124-131.

Badu, M., S. K. Twumasi and N. O. Boadi. 2011. Effects of lignocellulosic in wood used as substrate on the quality and yield of mushrooms. Food Nutr. Sci. 2: 780-784.

Bisaria, R., M. Madan and V. S. Bisaria. 1987. Biological efficiency and nutritive value of Pleurotus sajor-caju cultivated on different agro-wastes. Biol. Wastes 19: 239-255.

Carvalho, M. P., S. T. V. Der Sand, E. A. R. Rosa, J. C. Germani and N. K. Ishikawa. 2007. Investigation of the antibacterial activity of basidiomycetes. Biociencias, Porto Alegre 15: 173-179.

Chang, S. T. and P. G. Miles. 2004. Mushrooms Cultivation, Nutritional Value, Medicinal Effect and Environmental Impact. $2^{\text {nd }}$ ed. CRC Press LLC, USA. p. 451.

Daneshvar, M. H. and M. Heidari. 2008. Effects of wheat straw, leaves of date palm and alfalfa on oyster mushroom yield. $3^{\text {rd }}$ National Congress of Recycling and Reuse of Renewable Organic Resources in Agriculture.

David, O. M., E. D. Fagbohun, A. O. Oluyege and A. Adegbuyi. 2012. Antimicrobial activity and physicochemical properties of oils from tropical macro Fungi. J. Yeast Fungal Res. 3: 1-6.

Davis, R. A. and B. J. Aegerter. 2000. Edible Mushroom Cultivation. Scientific Publishers, Jodhpur, India. pp. 2-5.

Gregori, G., M. Svagelj, J. Pohleven. 2007. Cultivation techniques and medicinal properties of Pleurotus spp. Food Technol. Biotechnol. 45(3): 236-247.

Gupta, A., S. Sharma., S. Saha and S. Walia. 2013. Yield and 
nutritional content of Pleurotus sajor caju on wheat straw supplemented with raw and detoxified mahua cake. Food Chem. 141: 4231-4239.

Hamad, H. B. A. 2005. Effect of microbial biotechnical and media mixtures on production of oyster mushroom (Pleurotus ostreatus). M.Sc. Thesis, College of Agriculture, University of Anbar, Iraq.

Hassan, I. A. 2011. Effect of sterilization on the yield and storage life of oyster mushroom cultivated on date palm by products. M.Sc. Thesis, College of Agriculture, University of Baghdad, Iraq.

Hassan, S. A., W. H. Al-Samaraae and A. J. Hashim. 2008. Comparsion study between chemical and microbial treatment of ground and chopped frond and barley straw. Iraqi J. Agric. Sci. 39: 79-93.

Ismail, R. M., A. H. Rahif, K. M. Thaiaa, M. Saleh, S. Hussein and B. Sadeq. 2010. Study for the advancement of technology packages date palm field. Report. General Board of Date-Palm. Ministry of Agriculture, Iraq. p. 39.

Kabirifard, A. M., H. Fazaeli and F. Kafilzadeh. 2012. Comparing the growth rate of four Pleurotus fungi on wheat stubble and date palm leaf. J. Res. Agric. Sci. 8: 35-43.

Kalpana, R. S., A. K. Mishra and M. V. Nair. 2011. Polymeric products as effective biocide (antifungal agent) against deteriorating wood. Asiatic J. Biotechnol. Res. 2: 542-546.

Kashangura, C. 2008. Optimisation of the growth conditions and genetic characterisation of Pleurotus Species. Ph.D. Dissertation, Department of Biological Sciences, Faculty of Science, University of Zimbabwe.

Kim, J. H., S. J. Kim, H. R. Park, J. I. Choi, Y. C. Ju, K. C. Nam, S. J. Kim and S. C. Lee. 2009. The different antioxidant and anticancer activities depending on the color of oyster mushrooms. J. Med. Plants Res. 3: 1016-1020.

Kulshreshtha, S., N. Mathur, P. Bhatnagar and S. Kulshreshtha. 2013. Cultivation of Pleurotus citrinopileatus on handmade paper and cardboard industrial wastes. Ind. Crops Prod. 41: 340-346.

Mohamad, I. I., M. F. Hassan, S. N. Mohamad, L. C. Tin and M. R. Sarmidi. 2008. Production of Pleurotus sajor-caju on sawdust of rubber tree and empty palm fruit bunch. J. Chem. Nat. Res. Eng. 2: 14-23.
Onuoha, C. I. 2007. Cultivation of the mushroom (Pleurotus tuber regium) using some local substrates. Life Sci. J. 4: 58-61.

Owaid, M. N., S. S. S. Al-Saeedi and I. A. Al-Assaffii. 2015a. Antimicrobial activity of mycelia of oyster mushroom species (Pleurotus spp.) and their liquid filtrates (in vitro). J. Med. Bioeng. 4: 376-380.

Owaid, M. N., S. S. S. Al-Saeedi and I. A. Al-Assaffii. 2014. Impact palm date fibers (fibrillum) and sawdust extract on mycelial growth rate of four species of Pleurotus. $3^{\text {rd }}$ Scientific Conference for Plant Production. J. Tikrit Univ. Agric. Sci. 14: 1-7.

Owaid, M. N., S. S. S. Al-Saeedi, V. Sabaratnam, I. A. A. Al-Assaffii and J. Raman. 2015b. Growth performance and cultivation of four oyster mushroom species on sawdust and rice bran substrates. J. Adv. Biotechnol. 4: 424-429.

Poppe, J. 2004. Part II. Oyster Mushrooms, Substrate. In: Oyster Mushroom Cultivation. Vol. 1. Mush World, Aloha Medicinals Inc., Korea. pp. 75-85.

Ranjini, R. and T. Padmavathi. 2012. Phenol tolerance of Pleurotus florida under varying conditions of nitrogen sufficiency. Eur. J. Exp. Biol. 2: 75-82.

Sanchez, C. 2010. Cultivation of Pleurotus ostreatus and other edible mushrooms. Mini-Rev. Appl. Microbiol. Biotechnol. 85: 13211337.

Santos-Neves, J. C., M. I. Pereira, E. R. Carbonero, A. H. P. Gracher, P. A. J. Gorin, G. L. Sassaki and M. lacomini. 2008. A gel-forming $\beta$-glucan isolated from the fruit bodies of the edible mushroom Pleurotus florida. Carbohydr. Res. 343: 1456-1462.

Stamets, P. and J. S. Chilton. 1983. Mushroom Cultivator: A Practical Guide to Growing Mushrooms at Home. Agarikon Press, Washington. p. 415.

Tabi, A. N. M., F. A. Zakil, W. N. F. M. Fauzai, N. Ali and O. Hassan. 2008. The usage of empty fruit bunch (EFB) and palm pressed fiber (PPF) as substrates for the cultivation of Pleurotus ostreatus. J. Teknol. 49: 189-196.

Thomas, M. G. and D. R. Schumann. 1993. Income Opportunities in Special Forest Products-Self-Help Suggestions for Rural Entrepreneurs. Agriculture Information Bulletin AIB, U.S., Department of Agriculture, Washington. p. 139. 